\title{
Mitochondrial uncoupling does not influence the stability of the intracellular signal activating plasma membrane calcium channels ${ }^{\star}$
}

\author{
Krzysztof Zabłocki, Agnieszka Makowska and Jerzy Duszyński ${ }^{\bowtie}$ \\ Department of Cellular Biochemistry, Nencki Institute of Experimental Biology, Warszawa, Poland
}

Received: 15 February, 2001; accepted: 17 February, 2001

Key words: thapsigargin, Jurkat cells, store-operated calcium entry, mitochondrial uncoupling

\begin{abstract}
The effects of various concentrations of thapsigargin, a specific inhibitor of $\mathrm{Ca}^{2+}$-ATPase in the endoplasmic reticulum (ER) membrane, on calcium homeostasis in lymphoidal T cells (Jurkat) were investigated. Preincubation of these cells suspended in nominally calcium-free medium with $0.1 \mu \mathrm{M}$ thapsigargin resulted in a complete release of $\mathrm{Ca}^{2+}$ from intracellular calcium stores. When the medium was supplemented with $3 \mathrm{mM}$ $\mathrm{CaCl}_{2}$ the cells maintained constantly elevated level of cytosolic $\mathrm{Ca}^{2+}$. However, thapsigargin applied at lower concentration produced only a partial depletion of the stores. For example, in the cells pretreated with $1 \mathrm{nM}$ thapsigargin and suspended in calcium-free medium approximately $75 \%$ of the calcium content was released from the intracellular stores. The addition of $3 \mathrm{mM} \mathrm{CaCl} \mathbf{~}_{2}$ to such cell suspension led to a transient increase in cytosolic calcium concentration, followed by a return to a lower steady-state. This phenomenon, related to the refilling of the $\mathrm{ER} \mathrm{by} \mathrm{Ca}^{2+}$, allowed to estimate the half-time for the process of cell recovery after activation of store-operated calcium channels. By this approach we have found that carbonyl cyanide $m$-chlorophenylhydrazone, which has been documented to inhibit calcium entry into Jurkat cells, does not influence the stability of the intracellular signal involved in the activation of store-operated calcium channels.
\end{abstract}

Cytosolic free $\mathrm{Ca}^{2+}$ is the major second messenger in all types of cells. It regulates many crucial cytosolic processes, including gene expression, cell division, exocytosis, cell contraction and many metabolic reactions. Thereby, the cytosolic $\mathrm{Ca}^{2+}$ concentration $\left(\left[\mathrm{Ca}^{2+}\right]_{\mathrm{c}}\right.$ ) must be controlled in an extremely precise manner (Berridge, 1995).
In non-electrically excitable cells, the resting level of cytosolic free $\mathrm{Ca}^{2+}$ is as low as $100 \mathrm{nM}$, while in the main intracellular calcium stores localised in the endoplasmic reticulum (ER) it is estimated to be two orders of magnitude higher. Calcium concentration in the extracellular milieu is even higher and amounts to $1-2 \mathrm{mM}$; i.e., it is ten- to

\footnotetext{
ॠ Presented at the 36th Meeting of the Polish Biochemical Society, Poznań, 2000.

${ }^{凶}$ To whom correspondence should be addressed: Jerzy Duszyński, Department of Cellular Biochemistry, Nencki Institute of Experimental Biology, L. Pasteura 3, 02-093 Warszawa, Poland; phone: (48 22) 6598571 ext. 427; e-mail: jdus@nencki.gov.pl

Abbreviations: $\left[\mathrm{Ca}^{2+}\right]_{\mathrm{c}}$, cytosolic calcium concentration; SOC, store-operated calcium channel; CCCP, carbonyl cyanide m-chlorophenylhydrazone; DMSO, dimethylsulfoxide; ER, endoplasmic reticulum; PM, plasma membrane.
} 
twenty thousand times more concentrated than that in the cytosol.

These high concentration gradients are built up and kept at the cost of the energy from ATP by $\mathrm{Ca}^{2+}$-ATPases (calcium pumps) localised in the ER membranes and in the plasma membrane (PM). If the cell is activated by extracellular stimuli (for example by some hormones or growth factors) the low basal $\left[\mathrm{Ca}^{2+}\right]_{\mathrm{c}}$ changes into an elevated one. The key event in this physiological reaction is the depletion of intracellular calcium stores which leads to the opening of calcium channels in PM and massive calcium entry into the cell. As the activation of calcium influx depends on the filling state of ER calcium stores, these channels are called store-operated channels (SOC). This regulatory phenomenon was formerly known as the capacitative regulation of calcium entry (Putney, 1986; 1990). Although the physiological and biochemical importance of such activation of calcium influx has been well documented and repeatedly confirmed for many types of cells (Parekh \& Penner, 1997), the accurate signalling mechanism coupling ER to PM calcium channels has remained unknown so far. Similarly, the exact nature of SOC needs to be elucidated. Recently, it has been suggested that the store-operated calcium influx may be mediated by proteins homologous to transient receptor potential (TRP) family members (Kiselyov et al., 1998; Barrit, 1999, for review).

Under physiological conditions, a transient increase in $\left[\mathrm{Ca}^{2+}\right]_{\mathrm{c}}$ is followed by some regulatory processes leading to restoration of the original resting steady-state of calcium concentration. This events include fast and slow feed-back inhibitions of SOC by increased $\left[\mathrm{Ca}^{2+}\right]_{\mathrm{c}}$, an activation of the plasma membrane calcium pump and a replenishment of ER calcium stores (Parekh, 1998; Zweifach \& Lewis, 1995a; 1995b). In accordance with the hypothesis of the regulation of SOC activity, refilling of ER calcium stores should turn off signal transmission between ER and PM.

The depletion of ER calcium stores may be executed by thapsigargin, a selective inhibition of ER $\mathrm{Ca}^{2+}$-ATPase (Thastrup et al., 1994; Parekh \& Penner, 1997). On the other hand, thapsigargin inhibits $\mathrm{Ca}^{2+}$-ATP irreversibly and thus, at high concentrations, completely prevents the reloading of ER calcium stores. Moreover, thapsigargin must be used with caution because of its inhibitory side effects on SOC (Thastrup et al., 1994).

It has been recently demonstrated that mitochondria play an important role in the regulation of SOC (Gamberucci et al., 1994; Hoth et al. 1997; Fernando et al., 1998; Makowska et al., 2000). In various cell lines deenergisation of mitochondria greatly impaired the store-operated calcium influx (Waśniewska \& Duszyński, 2000). The aim of the present study was to investigate the mechanism of mitochondrial involvement in SOC regulation. We demonstrate that the energy state of mitochondria does not influence the stability of the intracellular signal involved in the activation of SOC by ER calcium stores.

\section{MATERIALS AND METHODS}

Materials. Fura-2/AM was purchased from Molecular Probes (Eugene, OR, U.S.A.). Ionomycin, oligomycin, thapsigargin and carbonyl cyanide $m$-chlorophenylhydrazone (CCCP) were from Sigma (St. Louis, MO, U.S.A.). Other chemicals were of analytical grade. The standard assay medium consisted of $130 \mathrm{mM} \mathrm{NaCl}, 5 \mathrm{mM} \mathrm{KCl}, 1 \mathrm{mM}$ $\mathrm{MgCl}_{2}, 0.5 \mathrm{mM} \mathrm{Na}{ }_{2} \mathrm{HPO}_{4}, 25 \mathrm{mM}$ Hepes, $1 \mathrm{mM}$ pyruvate and $5 \mathrm{mM}$ glucose, $\mathrm{pH}$ 7.2.

Cell cultures. Jurkat lymphoidal T-cell line was cultured in RPMI-1640 medium (Ludwik Hirszfeld Institute of Immunology and Experimental Therapy, Wrocław, Poland) supplemented with $10 \%$ foetal bovine serum (GIBCO BRL), 2 $\mathrm{mM}$ glutamine, penicillin (100 units $/ \mathrm{ml}$ ) and streptomycin $(50 \mu \mathrm{g} / \mathrm{ml})$ in a humidified atmosphere containing $5 \% \mathrm{CO}_{2}$ and $95 \%$ air at $37^{\circ} \mathrm{C}$, as described previously (Makowska et al., 2000).

\section{Measurements of intracellular calcium.} $\left[\mathrm{Ca}^{2+}\right]_{\mathrm{c}}$ was measured fluorimetrically using the fluorescent probe Fura-2. (Grynkiewicz et al., 1985). Jurkat cells suspended in the culture me$\operatorname{dium}\left(10^{6}\right.$ cells $\left./ \mathrm{ml}\right)$ were loaded with $1 \mu \mathrm{M}$ Fura-2/AM for $15 \mathrm{~min}$ at $37^{\circ} \mathrm{C}$. Then, the cells were washed by centrifugation with the standard assay medium containing $0.1 \mathrm{mM} \mathrm{CaCl} 2$ and suspended in the nominally calcium-free assay me- 
dium (containing $0.1 \mathrm{mM}$ EGTA instead of $\mathrm{Ca}^{2+}$ ) at $\mathrm{pH}$ 7.2. When indicated, $3 \mathrm{mM} \mathrm{CaCl} 2,1 \mu \mathrm{M}$ CCCP, and thapsigargin at the appropriate concentration were added to the cell suspension. The presence of both glucose and oligomycin in the cell suspension enabled cellular ATP to be kept at the unchanged level despite the impairment of oxidative phosphorylation. As oligomycin alone does not influence calcium entry into the cells, it was routinely added to all samples, including controls. Fluorescence was measured at $30^{\circ} \mathrm{C}$ in a Shimadzu RF5000 spectrofluorimeter set in the ratio mode using $340 / 380 \mathrm{~nm}$ wavelength for excitation and $510 \mathrm{~nm}$ for emission. The time resolution of the measurements was $1 \mathrm{~s}$. $\left[\mathrm{Ca}^{2+}\right]_{\mathrm{c}}$ was calibrated for cells in each run in the presence of 3 $\mathrm{mM}$ of externally added $\mathrm{CaCl}_{2}$ and $3 \mu \mathrm{M}$ ionomycin plus $0.002 \%$ digitonin.

\section{RESULTS AND DISCUSSION}

We tested the rate of calcium influx into Jurkat cells initially suspended in the nominally calcium-free medium and then pre-treated with various concentrations of thapsigargin. If the cells were pretreated with $0.1 \mu \mathrm{M}$ thapsigargin, subsequent addition of $\mathrm{CaCl}_{2}$ resulted in an immediate elevation of $\left[\mathrm{Ca}^{2+}\right]_{\mathrm{c}}$, that was not followed by any decrease towards the original steady-state (Fig. 1). Thapsigargin delivered at such high concentration totally inhibited $\mathrm{ER} \mathrm{Ca}^{2+}$-ATPase. Therefore, the refilling of ER calcium stores was impossible. This resulted in a sustained generation of SOC activating signal and, in consequence, the persistent activation of calcium influx. The plateau reached by $\left[\mathrm{Ca}^{2+}\right]_{\mathrm{c}}$ was a resultant of the activated calcium entry, gradually reduced by a feed-back inhibition of SOC, and calcium efflux from the cells, driven by PM calcium pumps. Figure 2 shows results of the titration of Jurkat cells with thapsigargin. After release of $\mathrm{Ca}^{2+}$ due to inhibition of ER $\mathrm{Ca}^{2+}$-ATPase, the remaining stored calcium was released by treatment of the cells with ionomycin. The total amount of $\mathrm{Ca}^{2+}$ which could be released by ionomycin is shown in Fig. 2A. We found that $0.1 \mu \mathrm{M}$ concentration of thapsigargin was high enough for a complete de- pletion of intracellular calcium stores (Fig. 2C) while pre-incubation of the cells with $1 \mathrm{nM}$

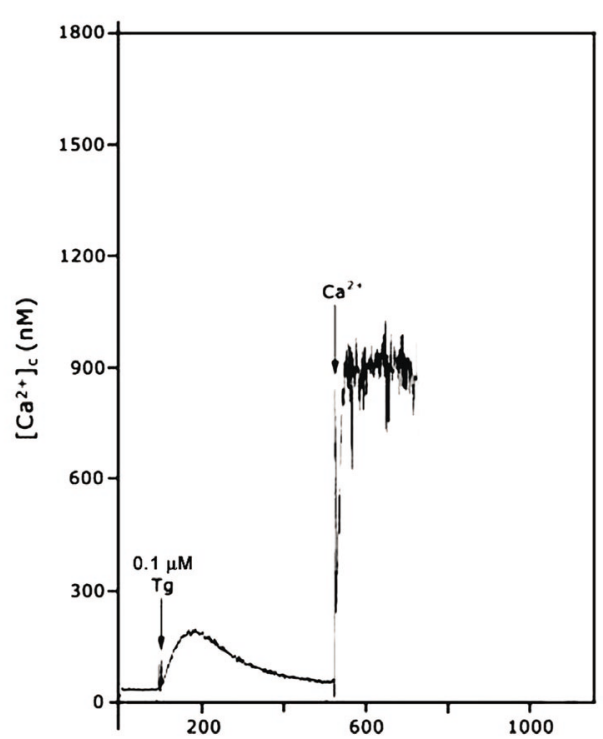

Figure 1. Changes in $\left[\mathrm{Ca}^{2+}\right]_{\mathrm{c}}$ in Jurkat cells pretreated with $0.1 \mu \mathrm{M}$ thapsigargin (Tg) and then exposed to $3 \mathrm{mM}$ extracellular $\mathrm{CaCl}_{2}$.

One trace typical of five is shown.

thapsigargin resulted in only a partial release of $\mathrm{Ca}^{2+}$ (Fig. 2B). Application of thapsigargin at still lower concentrations caused similar but weaker effects on the ER calcium content unless its concentration was lower than $0.25 \mathrm{nM}$. Below this concentration, thapsigargin was poorly effective (data not shown).

As shown in Fig. 3A, the addition of $\mathrm{CaCl}_{2}$ to the suspension of Jurkat cells pretreated with $1 \mathrm{nM}$ thapsigargin resulted in a fast but transient elevation of $\left[\mathrm{Ca}^{2+}\right]_{\mathrm{c}}$. The initial rate of $\mathrm{Ca}^{2+}$ influx (expressed as the rate of $\left[\mathrm{Ca}^{2+}\right]_{\mathrm{c}}$ changes) amounted to $46 \pm 7 \mathrm{nM} \times \mathrm{s}^{-1}$ and was similar to the influx rate after pretreatment of the cells with $0.1 \mu \mathrm{M}$ thapsigargin $\left(47 \pm 4 \mathrm{nM} \times \mathrm{s}^{-1}\right.$ ) (calculated for three independent experiments). This indicates that the intensity of the signal transmitted from ER to PM did not depend on the degree of emptying of ER calcium stores, at least in this range of thapsigargin concentration. Alternatively, in the presence of higher concentrations of thapsigargin and a complete depletion of ER stores, activation of a hypothetical signal coupling ER to PM considerably exceeded the level needed for full activation of SOC. Figures 1 and 3 also show that the 

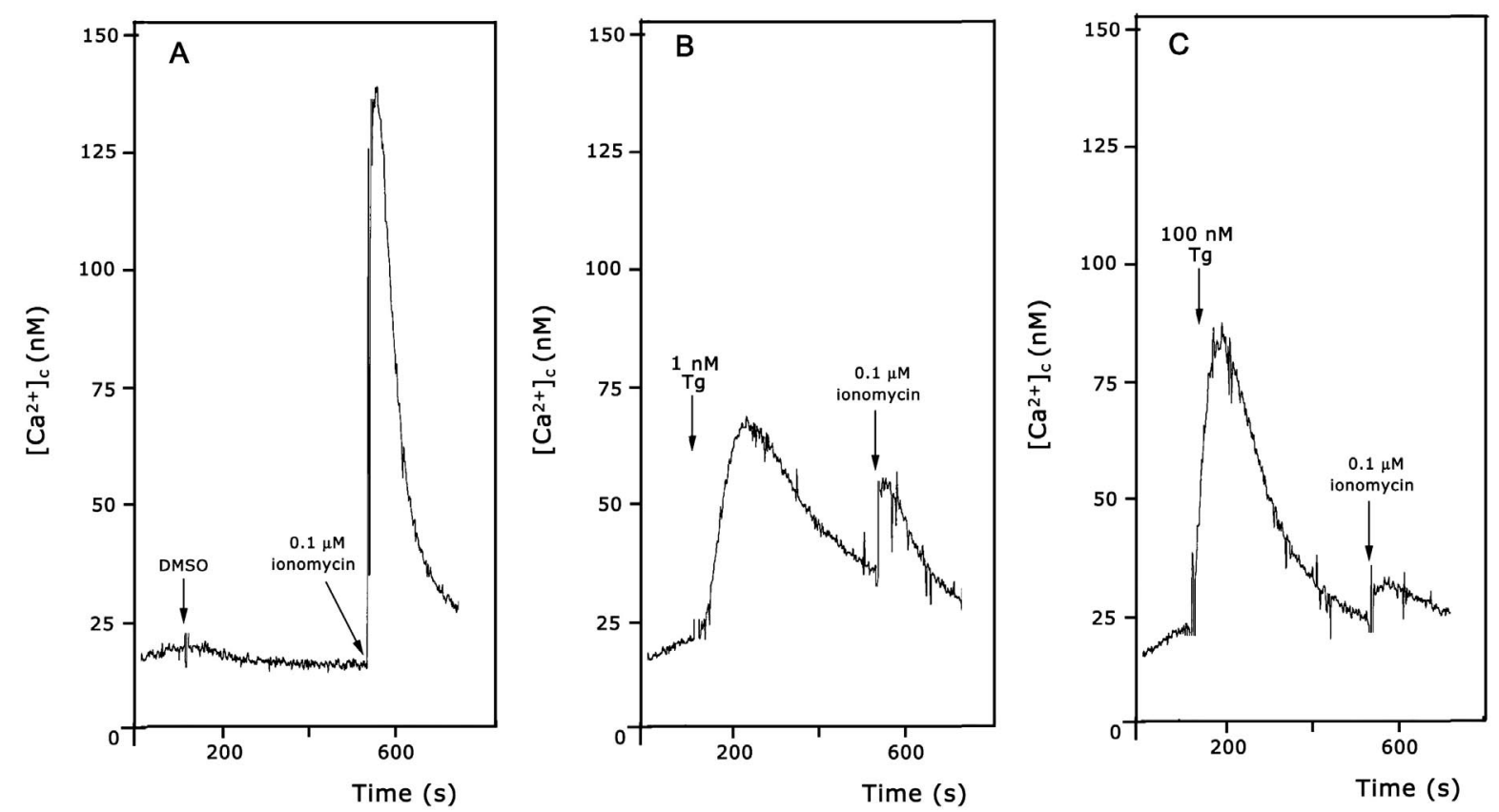

Figure 2. The effect of different concentrations of thapsigargin on the degree of $\mathrm{Ca}^{2+}$ release from intracellular stores.

The cells were pretreated with DMSO alone (A), $1 \mathrm{nM}$ thapsigargin (Tg) (B) and $0.1 \mu \mathrm{M}$ thapsigargin (C). One trace typical of three is shown.

maximal level of $\left[\mathrm{Ca}^{2+}\right]_{\mathrm{c}}$ resulting from calcium influx into the cells was dependent on the concentration of thapsigargin used; it was much lower in and SOC closure in consequence of the refilling of ER stores. It also reflects, to some extent, the stability of the hypothetical SOC-opening signal. Pre-
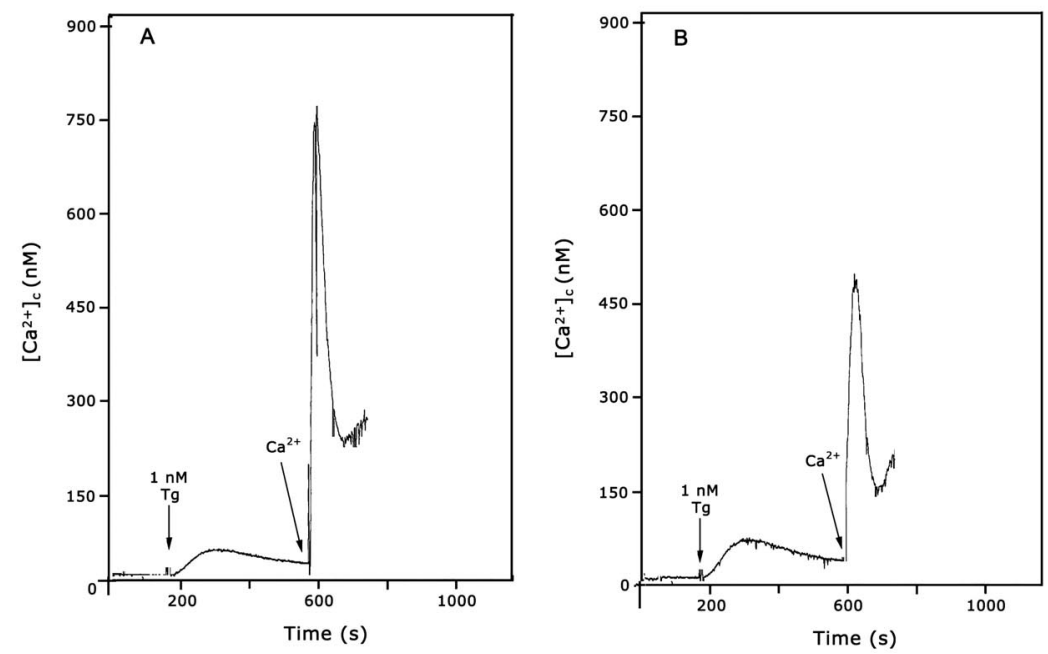

Figure 3. The effect of CCCP on changes in $\left[\mathrm{Ca}^{2+}\right]_{c}$ in Jurkat cells pretreated with $1 \mathrm{nM}$ thapsigargin (Tg) and then exposed to extracellular $\mathrm{CaCl}_{2}$.

A. Control cells. B. Cells preincubated with CCCP. One trace typical of three is shown. the case of cells preincubated in the presence of 1 $\mathrm{nM}$ thapsigargin than with $100 \mathrm{nM}$ thapsigargin.

The slope of the descending part of the curve represents a decrease in $\mathrm{Ca}^{2+}$ concentration resulting from both $\mathrm{Ca}^{2+}$ extrusion from the cells sumably, the rate of SOC closure depends on the disappearance of the signal that had been generated by ER until ER calcium stores became reloaded (Hofer et al., 1998). This pattern of $\left[\mathrm{Ca}^{2+}\right]_{\mathrm{c}}$ changes allowed us to estimate the half-time of 
reaching the new steady-state calcium level. In other words, the half-time of the cell recovery after signalling between ER and PM has been broken. This parameter may be useful to characterise the regulation of calcium homeostasis in various types of cells or in cells challenged by different extracellular stimuli.

We have previously described the inhibitory effect of a mitochondrial uncoupler (CCCP) on the rate of calcium entry into Jurkat cells preincubated with $1 \mu \mathrm{M}$ thapsigargin (Makowska et al., 2000). It was then evidenced that the decrease in the mitochondrial membrane potential influenced the initial rate of the calcium influx. Figures $3 \mathrm{~A}$ and $B$ show that CCCP inhibits the calcium entry into Jurkat cells pretreated with $1 \mathrm{nM}$ thapsigargin as well, but it does not exert any significant effect on the half-time of cell recovery; it amounted to $25 \mathrm{~s}$ for both control and CCCPtreated cells. In our previous paper (Makowska et al., 2000) it was concluded that CCCP did not change the rate of calcium efflux from the cells. If so, our present observations indicate that the stability (the half-time) of the intracellular signal involved in the activation of SOC by ER calcium stores was not reduced even if the mitochondrial membrane potential was collapsed. This observation additionally supports our former conclusion that mitochondrial potential was essential for SOC activation to occur but it was not involved in the regulation of cell recovery.

\section{R E F E R E N C E S}

Barrit, G.J. (1999) Receptor-activated $\mathrm{Ca}^{2+}$ inflow in animal cells: A variety of pathways tailored to meet different intracellular $\mathrm{Ca}^{2+}$ signalling requirements. Biochem. J. 337, 153-169.

Berridge, M.J. (1995) Capacitative calcium entry. Biochem. J. 312, 1-11.

Fernando, C.K., Gregory, R.B. \& Barritt, G.J. (1998) Protein kinase A regulates the disposition of $\mathrm{Ca}^{2+}$ which enters the cytoplasmic space through storeactivated $\mathrm{Ca}^{2+}$ channels in rat hepatocytes by diverting inflowing $\mathrm{Ca}^{2+}$ to mitochondria. Biochem. J. 267, 877-884.

Gamberucci, A., Innocenti, B., Fulceri, R., Banhegy, G., Giunti, R. \& Benedetti, A. (1994) Modulation of
$\mathrm{Ca}^{2+}$ influx dependent on store depletion by intracellular adenine-guanine nucleotide levels. J. Biol. Chem. 296, 23597-23602.

Grynkiewicz, G., Poenie, M. \& Tsien, R.Y. (1985) A new generation of $\mathrm{Ca}^{2+}$ indicators with greatly improved fluorescence properties. J. Biol. Chem. 260, 3440-3450.

Hofer, A.M., Fasolato, C. \& Pozzan, T. (1998) Capacitative $\mathrm{Ca}^{2+}$ entry is closely linked to the filling state of internal $\mathrm{Ca}^{2+}$ stores: A study using simultaneous measurements of ICRAC and intraluminal $\left[\mathrm{Ca}^{2+}\right]$. J. Cell Biol. 140, 325-334.

Hoth, M., Fanger, C.M. \& Lewis, R.S. (1997) Mitochondrial regulation of store-operated calcium signaling in T lymphocytes. J. Cell Biol. 137, 633-648.

Kiselyov, K., Xu, X., Mozhayeva, G., Kuo, T., Pessah, I., Mignery, G., Zhu, X., Birnbaumer, L. \& Muallem, S. (1998) Functional interaction between $\mathrm{InsP}_{3}$ receptors and store-operated Htrp3 channels. Nature 396, $478-482$.

Makowska, A., Zabłocki, K. \& Duszyński, J. (2000) the role of mitochondria in the regulation of calcium influx into Jurkat cells. Eur. J. Biochem. 267, 877-884.

Parekh, A.B. (1998) Slow feedback inhibition of calcium release-activated calcium current by calcium entry. J. Biol. Chem. 273, 14925-14932.

Parekh, A.B. \& Penner, R. (1997) Store depletion and calcium influx. Physiol. Rev. 77, 901-929.

Putney, J.W. (1986) A model for receptor-regulated calcium entry. Cell Calcium 7, 1-12.

Putney, J.W. (1990) Capacitative calcium entry revisited. Cell Calcium 11, 611-624.

Thastrup, O., Dawson, A.P., Scharff, O., Foder, B., Cullen, P.J. Drobak, B.K., Bjerrum, P.J., Christensen, S.B. \& Hanley, M.R. (1994) Thapsigargin, a novel molecular probe for studying intracellular calcium release and storage. Agents Action 43, 187-193.

Waśniewska, M. \& Duszyński, J. (2000) The role of mitochondrial dysfunction in regulation of store-operated calcium channels in glioma $\mathrm{C} 6$ and human fibroblast cells. FEBS Lett. 478, 237-240.

Zweifach, A. \& Lewis, R.S. (1995a) Slow calcium-dependent inactivation of depletion-activated calcium current. Store-dependent and -independent mechanisms. J. Biol. Chem. 270, 1444514451 .

Zweifach, A. \& Lewis, R.S. (1995b) Rapid inactivation of depletion-activated calcium current $\left(\mathrm{I}_{\mathrm{CRAC}}\right)$ due to local calcium feedback. J. Gen. Physiol. 105, 209-226. 